\title{
PROBLEMATIKA REFORMA AGRARIA PADA TANAH REDISTRIBUSI BEKAS HGU TRATAK, BATANG
}

\author{
Koes Widarbo
}

\author{
Sekolah Tinggi Pertanahan Nasional \\ Jl. Tata Bumi No. 5 Banyurade, Sleman, Yogyakarta \\ Corresponding author: widarbokoes2@gmail.com.id
}

Vol 1, No. 1
April 2021

Received

April 27 2021

Accepted

May $21^{\text {th }} 2021$

\begin{abstract}
The redistribution of land as a means of agrarian reform in Trumben Village, Bandar District, Batang, Central Java Province comes from the former HGU No.1 Tratak. The former HGU was successfully processed into State General Reserves Land (TCUN), then became Landreform Object Land covering an area of 079.8410 hectare since December 11th, 2015. The object was given to 425 heads of farmer families who had been working on the land. Each farmer receives one plot of land and cannot be transferred without hot official permits. Post-land redistribution, since 2018 the construction of Study Education Outside the Main Campus (PSDKU) UNDIP has begun. In line with this, problems arise, including the transfer of redistribution land ownership to external parties without permission, and the existence of agricultural land parcels for residential houses in the redistribution area. The purpose of this research is to see whether the UNDIP campus construction occurs in the rules of land redistribution transfer and how the alternative solutions to the existing problems. This study used an empirical juridical method with qualitative descriptive data analysis. The conclusion of this research is that the PSDKU development has an impact on the transfer of ownership and changes in the use of agricultural land to non-agricultural.
\end{abstract}

Keywords : agrarian reform, former HGU Tratak, illegal housing

\section{INTISARI}

Redistribusi tanah sebagai salah satu wujud penyelenggaraan reforma agraria di Desa Trumben, Kecamatan Bandar, Kabupaten Batang, Provinsi Jawa Tengah berasal dari bekas HGU No. 1 Tratak. Bekas HGU tersebut kemudian diproses menjadi Tanah Cadangan Umum Negara (TCUN), dan selanjutnya ditetapkan menjadi Obyek Landreform seluas 79,8410 hektar sejak Tanggal 11 Desember 2015. Objek tersebut diberikan kepada 425 kepala keluarga petani yang selama ini menggarap tanah tersebut. Masing-masing petani menerima satu bidang tanah Hak Milik (HM) dan tidak boleh dialihkan tanpa izin pejabat yang berwenang. Pasca redistribusi tanah tersebut, sejak tahun 2018 telah dimulai pembangunan Pendidikan Studi Di luar Kampus Utama (PSDKU) UNDIP. Sejalan dengan hal tersebut timbul permasalahan, antara lain adanya peralihan kepemilikan tanah redistribusi kepada pihak eksternal tanpa izin, serta adanya pengkaplingan tanah pertanian untuk rumah tinggal dalam area redistribusi tersebut. Tujuan penelitian ini adalah untuk mengetahui apakah pembangunan kampus UNDIP mengakibatkan terjadinya pelanggaran terhadap aturan peralihan tanah redistribusi tersebut serta bagaimana alternatif solusi dari permasalahan yang ada. Penelitian ini menggunakan metode kualitatif deskriptif dengan pendekatan yuridis empiris. Kesimpulan dari penelitian ini adalah pembangunan PSDKU berdampak pada peralihan kepemilikan dan perubahan penggunaan tanah pertanian menjadi non pertanian.

Kata kunci : Reforma Agraria, Bekas HGU Tratak, dan perumahan illegal

\section{A. Pendahuluan}

Salah satu kebijakan yang dilakukan Pemerintah Indonesia dalam menata kembali kepemilikan, penguasaan, pemanfaatan, dan penggunaan tanah adalah melalui reforma agraria (Sutadi et al, 2018). Ketimpangan penguasaan tanah 
ditandai dengan sebagian kecil orang menguasai sebagian besar tanah dan sebaliknya sebagian besar orang hanya menguasai tanah dengan luas yang sedikit. Penguasaan tanah yang timpang merupakan penyebab utama lahirnya ketimpangan agraria (Mujiburohman, 2019). Ketimpangan penguasaan tanah, secara umum dimulai dengan pemberian izin/hak pemanfaatan oleh pejabat publik yang mengeksklusi sekelompok rakyat dari tanah (Kantor Staf Presiden, 2016). Reforma agraria merupakan jawaban untuk permasalahan agraria, serta sebagai sarana menuju pemerataan kesejahteraan dalam rangka mewujudkan kemakmuran rakyat yang diamanatkan dalam Pasal 33 UUD 1945. Berangkat dari ketimpangan pemilikan tanah maka melalui Undang-Undang Pokok Agraria (UUPA), antara lain dalam Pasal 1 dan Pasal 2 ayat (1) kewenangan pengaturan negara melalui penataan kembali struktur penguasaan, pemilikan, penggunaan dan pemanfaatan tanah (P4T) bagi rakyat yang lebih berkeadilan melalui penataan aset dan aksesnya sebagaimana dimaksud dalam TAP MPR No. IX/MPR/2001 yang kemudian tindaklanjut dengan Peraturan Presiden No. 86 Tahun 2018 tentang Reforma Agraria.

Kesejahteraan masyarakat melalui pemanfaatan agraria yang adil dan berkelanjutan merupakan salah satu sasaran strategis Kementerian Agraria dan Tata Ruang/Badan Pertanahan Nasional (ATR/BPN) (Istiningdyah et al, 2018). Reforma Agraria adalah salah satu bagian dari butir 5 Nawacita yang menjadi agenda prioritas nasional untuk meningkatkan keadilan sosial dan kesejahteraan rakyat (Hidayat, 2020). Hal ini sesuai dengan cita-cita dari reforma agraria yaitu, tercapainya Penataan Aset atau Legalisasi Aset dan Penataan Akses atau Access Reform (Riyadi, 2020). Adapun berdasarkan Perpres No.86 tahun 2018, penataan aset yaitu penataan kembali atas struktur dari P4T dalam rangka mewujudkan keadilan di bidang penguasaan dan pemilikan tanah. Sedangkan penataan akses, pemberian kesempatan akses berupa modal dan bantuan lain bagi subjek reforma agraria guna peningkatan kesejahteraannya berbasis pemanfaatan tanah (pemberdayaan masyarakat). Redistribusi tanah sebagai salah satu upaya mengurangi ketimpangan penguasaan dan pemilikan tanah terutama bagi penggarap dan petani gurem (Mujiati, 2014). Salah satu objek reforma agraria dalam konteks ini adalah redistribusi tanah bekas Hak Guna Bangunan No. 1 PT. Perkebunan Tratak (HGU No. 1 Tratak), seluas $89.841 \mathrm{~m} 2$ yang peruntukkan dan penggunaannya untuk perkebunan karet, kopi, dan cengkeh yang telah ditetapkan sebagai tanah terlantar. Tanah tersebut kemudian seluas $79.841 \mathrm{~m} 2$ diredistribusikan kepada petani atau penggarap.

Penelitian terkait dengan reforma agraria atau redistribusi tanah telah dilakukan oleh beberapa peneliti sebelumnya diantaranya; Pertama, Budhiawan \& Widarbo (2020), adanya pengalihan kepemilikan tanah secara ilegal dari sekelompok petani penggarap tanpa izin pejabat yang berwenang pasca redistribusi tanah. Kedua, Mujiburohman (2018) meneliti implikasi pembatalan suat keputusan penetapan tanah terlantar adalah tidak dapat didayagunakan untuk kepentingan masyarakat dan negara. Ketiga, Saputra (2015) berfokus pencapaian Omah Tani dalam penyelesaian beberapa kasus tanah dan menyertai petani penggarap dalam 
proses gugatan PT. Perkebunan Tratak. Keempat, Westi Utami (2016) meneliti keberhasilan usaha dan upaya petani penggarap atas tanah bekas HGU Tratak Batang serta peningkatan daya guna dan kemampuan berproduksi masyarakat yang dikelola dengan program reforma agraria, sehingga dapat manifestasikan kesejahteraan rakyat. Kelima Hidayat et al (2020), penelitian yang mendesain reforma agraria inklusif yang menggabungkan Program Keluarga Harapan (PKH) dan kaum difabel sebagai subjek dan tanah negara bekas hak guna usaha di Desa Sempu, Kecamatan Ngancar, Kabupaten Kediri. Sebagai gagasan baru dalam penyelesaian reforma agraria mulai dari penataan aset melalui pemberian hak milik bersama dan perorangan dengan redistribusi tanah dilanjutkan dengan penataan akses yang melibatkan sinergi stakeholder. Keenam, Dempo et al (2021), pelaksanaan redistribusi tanah di kawasan hutan dilakukan dengan pengukuhan kawasan hutan, masalah yang dihadapi yaitu pelepasan kawasan hutan yang baru sampai pada tahap berita acara tata batas, revisi Rencana Tata Ruang Wilayah (RTRW) sedang berjalan, dan beberapa kekurangan kelengkapan administrasi yang seharusnya bisa diselesaikan dengan tepat dengan koordinasi yang baik antara stakeholder yang terlibat.

Adapun tujuan dari penelitian ini adalah pertama untuk mengetahui apakah pembangunan PSDKU UNDIP Batang berdampak atas pelanggaran penjualan tanah redis kepada pihak ketiga (investor) dan pengaplingan pembangunan perumahan yang keduanya ilegal tanpa adanya ijin pejabat yang berwenang; kedua, untuk memberikan alternatif solusi untuk penyelesaiannya.

Berdasarkan penelaahan dari penelitian terdahulu diperoleh kesimpulan bahwa penelitian ini berbeda dengan penelitian yang telah ada sebelumnya. Tulisan ini membahas dampak pasca redistribusi tanah HGU Tratak yang telah ditetapkan sebagai tanah terlantar dan secara khusus dampak pembangunan kampus UNDIP yang berasal dari tanah cadangan negara.

\section{B. Metode Penelitian}

Penelitian ini menggunakan metode penelitian yuridis empiris atau sosiologis hukum yaitu salah satu jenis penelitian di bidang yuridis dengan menelaah dan menyelidiki bekerjanya hukum dalam kehidupan masyarakat atau mengkonsepkan hukum selaku perbuatan realita (Ishaq, 2017). Metode ini dipilih untuk mengetahui dampak pembangunan kampus UNDIP dengan mempelajari terjadinya perubahan lingkungan yang dapat berakibat pada perubahan perilaku bagi petani penerima redistribusi, dan masukan pertimbangan konsep strategi pemberdayaannya bagi pihak berwenang yang terkait. Data yang dibutuhkan yaitu data primer dan sekunder. Data primer diperoleh dari pengumpulan data lapang pada tahun 2020, dengan sumber data diperoleh langsung di lokasi penelitian, serta peristiwa hukum yang terkait. Pengumpulan data dilaksanakan pada tahun 2020. Responden terpilih melalui pemilihan populasi dan sampelnya memberikan keterangan terkait dengan cara wawancara. Data sekunder berfungsi sebagai penyokong data primer yang didapatkan dari sumber online maupun offline. Adapun analisis data untuk menjawab rumusan masalahnya digunakan secara deskriptif kualitatif. Gambar berikut 
adalah peta administrasi lokasi penelitian, yaitu Desa Tumbrep Kecamatan Bandar Kabupaten Batang.

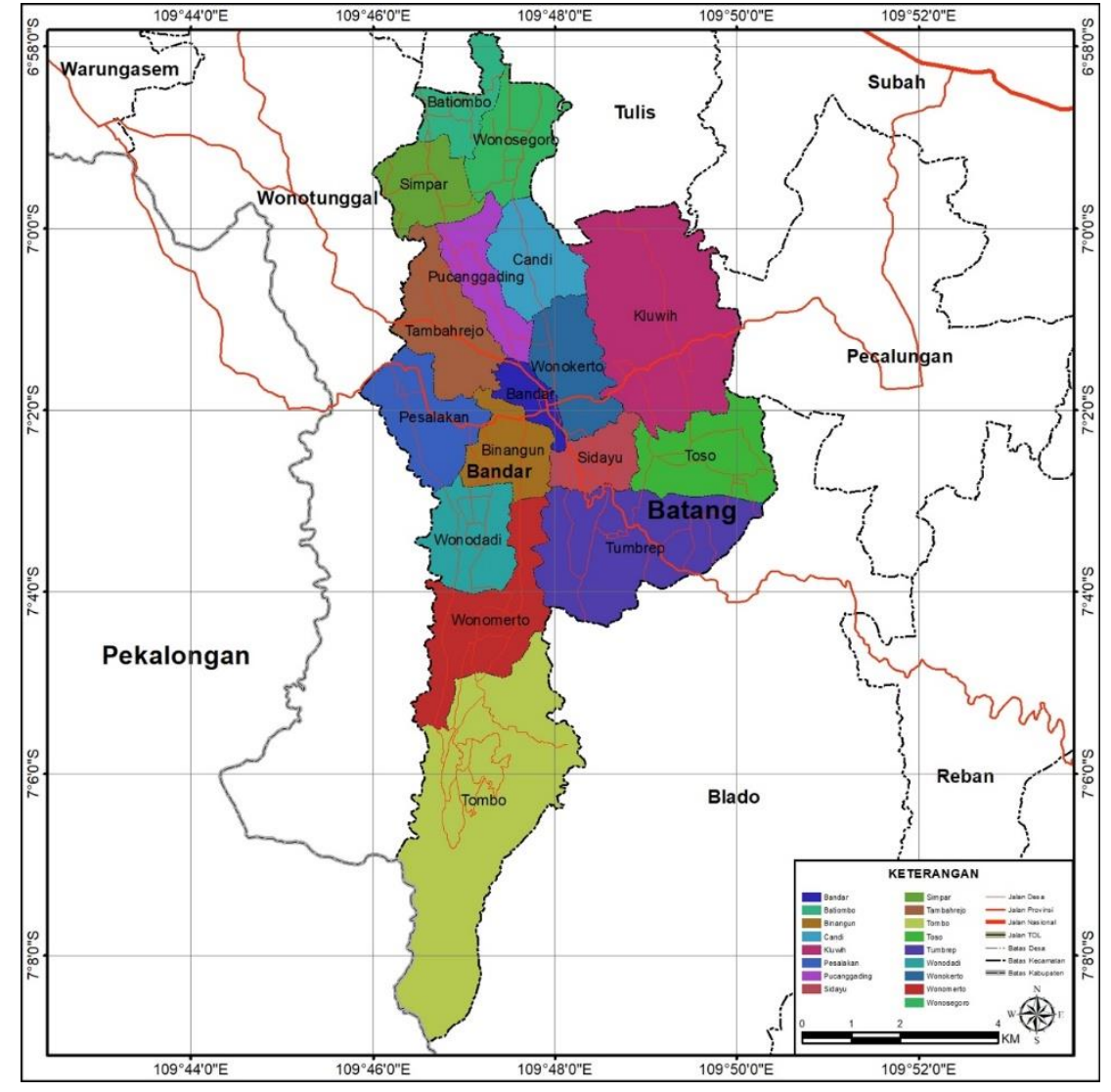

Gambar 1. Peta Administrasi Kecamatan Bandar

Sumber: Peraturan Bupati Batang No 07 Tahun 2011 Tentang RTRW Kabupaten Batang Tahun $2011-2031$

\section{Masalah Redistribusi Tanah Bekas HGU}

Permasalahan pertama berawal dari peruntukkan dan penggunaan tersebut oleh perusahaan hanya seluas $74.000 \mathrm{~m} 2$ dari total luas HGU sebesar $898.410 \mathrm{~m} 2$. Dalam pengelolaan HGU tersebut, terjadi manipulasi pengelolaan dengan model kontrak pada tahun 1987-1988 dengan PT.Pabrik Gula Cepiring dan tahun 19881989 dengan PT.Pabrik Gula Sragi. Pada tahun 1990, dilakukan penebangan terhadap pohon karet yang tidak berproduksi namun tidak dilakukan peremajaan kembali, sehingga menjadi terlantar dengan semak belukar. Sehubungan dengan hal tersebut, perusahaan mengontrakkan area sisanya seluas $790.000 \mathrm{~m} 2$ tersebut kepada warga di sekitar Desa Trumbep. Dasar pengelolaan tersebut adalah Surat Kepala Dinas Perkebunan Provinsi Tgl. 19-04-2011 No.525.1/2862 dan Surat Kepala Dinas Kehutanan dan Perkebunan Kabupaten Batang Tgl. 20-04-2011 No.525.1/342, yang menyatakan bahwa klasifikasi perkebunan besar Kelas III predikat sedang dinilai sangat kurang. Dampak kegagalan pengelolaan lahan HGU tersebut berakibat warga masyarakat melakukan penggarapan dan terjadi konflik dengan perusahaan. Upaya penyelesaian konflik tersebut difasilitasi oleh Pemerintah Kabupaten (Pemkab) Batang. Dengan pertimbangan kemaslahatan masyarakat yang tidak mempunyai lahan pertanian maka diterbitkan rekomendasi Bupati Ba- 
tang No.593.3/867/2004 tertanggal 10 September 2004 yang merekomendasikan bahwa lahan konflik HGU No.1 Tratak ditetapkan sebagai tanah obyek landreform.

Berdasarkan hal tersebut di atas, Forum Paguyuban Petani Nelayan Batang (FP2NB) memohon kepada Kepala Kantor Wilayah Badan Pertanahan Nasional (Kanwil BPN) Provinsi Jawa Tengah dengan surat No.593/02361 tertanggal 27 Februari 2008, agar HGU No.1 yang ditelantarkan tersebut dibatalkan untuk kemudian diredistribusikan bagi petani yang menggarap lahan tersebut secara eksisting dan terus menerus.Kanwil BPN Provinsi Jawa Tengah berdasarkan Pasal 4 ayat (2) Peraturan Pemerintah No. 11 Tahun 2010 tentang Tanah Terlantar, melakukan pemantauan terhadap tanah tersebut. Panitia C Kanwil BPN Provinsi Jawa Tengah kemudian berdasarkan berita acara hasil penyelidikan pencatatan fakta dengan peninjauan tertanggal 4 April 2011 telah melakukan 3 kali teguran yaitu: 1) Teguran I pada tanggal 13 Mei 2011; 2) Teguran II pada tanggal 14 Juni 2011; dan 3) Teguran III pada tanggal 15 Juni 2011; namun pemegang HGU tidak menindaklanjuti sesuai dengan peruntukkan dan penggunaannya. Berdasarkan hal tersebut Kepala Kanwil BPN Provinsi Jawa Tengah mengusulkan penetapan tanah terlantar kepada Kepala BPN RI dengan suratnya tanggal 3 Oktober 2011 No.5748/16.500/X/33/2011. Sebagai tindak lanjut atas surat usulan tersebut, pada tanggal 16 Agustus 2013 dengan Surat Keputusan (SK) Kepala BPN RI tertanggal No.7/PPT-HGU/BPNRI/2013 HGU No.1 Tratak seluas 898.410 M2 ditetapkan menjadi tanah terlantar.

Pemegang HGU No.1 Tratak mengajukan gugatan atas SK Kepala BPN tersebut kepada Pengadilan Tata Usaha Negara (PTUN) dengan Surat No.25/G/2013/ PTUN.JKT, namun gugatan ditolak dan pemegang hak tersebut tidak mengajukan banding; sehingga SK penetapan tanah terlantarnya menjadi sah. Sebagai tindak lanjut terhadap HGU No.1/Tratak Desa Trumbep tersebut, berdasarkan SK Menteri Agraria dan Tata Ruang/Kepala BPN tertanggal 14 November 2015 No.424/23.3/ $\mathrm{XI} / 2015$, mengatur 2 (dua) hal pokok. Pertama, menetapkan Cadangan Umum Negara (TCUN) tanah seluas $79.841 \mathrm{Ha}$ untuk penggunaan kepentingan masyarakat melalui reforma agraria (redistribusi Tanah) dan 100.000 m2 untuk Tanah Cadangan Negara (TCN). Kedua, memerintahkan Kepala Kanwil BPN Provinsi Jawa Tengah untuk melaksanakan redistribusi tersebut kepada 425 kepala keluarga (KK) petani penggarapnya dan pemberian objek TCUN dan cadangan negara lainnya, disesuaikan dengan Rencana Umum Tata Ruang (RTRW) dengan berkoordinasi Pemerintah Kabupaten Batang. TCUN adalah Tanah Objek Reforma Agraria (TORA) sebagaimana dimaksud dalam Perpres No. 86 Tahun 2018. Tahap redistribusi dilaksanakan berdasarkan Petunjuk Pelaksanaan (Juklak) Redistribusi Tahun 2015 dengan output kegiatan berupa penyerahan sertipikat Hak Milik kepada 425 KK petani. Selain diperuntukan untuk kegiatan redistribusi tanah, bekas HGU No 1 Tratak juga diperuntukan untuk Pembangunan gedung Pendidikan Studi Luar Kampus Utama (PSDKU) Perguruan Tinggi Negeri (PTN) Universitas Diponegoro (UNDIP) yang letaknya tepat berbatasan di sebelah Timur Laut lokasi reforma agraria. Tujuan dibukanya PSDKU ini sejalan dengan Per.Dikti.No.1 Th.2017, yakni mengoptimalkan akses, kesetaraan, kualitas, dan hubungan pendidikan tinggi di 
seluruh Indonesia dan mengoptimalkan kualitas, dan hubungan penelitian ilmiah serta pengabdian masyarakat untuk menunjang Pembangunan Nasional.

Asal usul perolehan tanah Kampus PSDKU UNDIP dan tanah lokasi reforma agraria adalah keduanya sama-sama dari tanah terlantar yang berasal dari bekas HGU No.1/Tratak. Tanah reforma agraria berasal dari tanah terlantar yang menjadi TCUN, sedangkan tanah kampus PSDKU UNDIP berasal dari Tanah Terlantar yang menjadi Tanah Cadangan Negara (TCN). Berdasarkan SK Menteri ATR/Kepala BPN No.424/23.3/XI/2015 TCUN dan cadangan negara lainnya, disesuaikan dengan Rencana Umum Tata Ruang (RTRW) 2011-2030 yaitu kawasan peruntukan pertanian. Dari luas total TCN $100.000 \mathrm{~m} 2$, seluas $94.000 \mathrm{~m} 2$ diberikan oleh Menteri ATR/Kepala BPN kepada Pemkab Batang dan sisanya merupakan aset Kementerian ATR/BPN. Menurut keterangan Rini Sumiati (2020) Kasi Penataan Pertanahan dan Pemberdayaan (PPP), asal usul lahan PSDKU UNDIP adalah hibah dari tiga sertipikat Hak Pakai Pemerintah Kabupaten Batang yang sudah melalui proses dan persetujuan DPRD Kabupaten Batang, dan telah sesuai dengan RTRW dan ketentuan regulasi yang berlaku.

Subyek penerima redistribusi tanah adalah petani penggarap lahan yang melakukan sewa menyewa dengan PT. Tratak Perkebunan, saat HGU tersebut masih aktif. Para petani ini berasal dan bertempat tinggal di Desa Wonomerto Kecamatan Bandar sejumlah 125 KK, Desa Kambangan Kecamatan Blado sejumlah 230 KK, di Dukuh Kambangan sejumlah 150 KK, Dukuh Perdisar sejumlah 70 KK di, serta 50 KK di Dukuh Cepoko Desa Trumbep.

Adapun harga pasar objek area bagian lokasi tanah redsitribusi terdiri atas 4 klasifikasi. Pertama, letak objek posisi di bagian di tepi sarana jalan desa (aspal) dan seberang jalan dekat UNDIP harga sebelumnya Rp.200.000,-.(dua ratus ribu rupiah), saat transaksi Th.2019-2020 sudah mencapai Rp.1.500.000,-.. Kedua, letak objek posisi di tepi jalan desa (aspal) selain butir (a) tersebut di atas; harga sebelumnya Rp.100.000,-, (seratus ribu rupiah) sampai dengan Rp.200.000,. (dua ratus ribu rupiah)/per-meter persegi, saat ini mencapai Rp.500.000,-.(lima ratus rupiah)/per meter persegi. Ketiga, letak objek posisi tidak di tepi jalan, selain/sebelah barat dari butir (a) dan (b) hanya tersedia jalan bantu (hak pengabdian/fungsi sosial) yang disepakati oleh para petani; harga sebelumnya Rp.50.000,-. (lima ribu rupiah), saat ini mencapai Rp.200.000,-.(dua ratus ribu rupiah)/permeter persegi. Keempat, letak objek posisi di dalam, di tepi Sungai Tambangan harganya masih tetap Rp.50.000,-.(lima puluh ribu)/per-meter persegi.

Tingkat kesuburan tanah sesuai dengan letak objek terdiri atas 2 klasifikasi. Pertama, letak objek di area posisi terdalam, di tepi Sungai Tambangan yaitu merupakan area lokasi tanah yang subur, ditanami sawah. Sedangkan selain posisi klasifikasi kedua, letak objek di area tepi Jalan aspal kabupaten dan lebih ke dalam (sebelah barat jalan aspal kabupaten), maka jenis lahan tanahnya tidak sesubur untuk lahan sawah karena jauh dari Sungai Tambangan, sehingga ditanami palawija dan pohon sengon.

Permasalahan kedua, adanya pengalihan secara ilegal 40 objek yang diperjualbelikan di bawah tangan kepada pihak eksternal (investor). Para petani memahami bahwa hal tersebut melanggar ketentuan larangan memindahtangan- 
kan lahan redis ke pihak lain sebagian atau seluruhnya sebelum 10 tahun sejak tanah tersebut didaftarkan sebagai hak milik (HM), sebagaimana tercantum dalam SK Pemberian hak dan sertipikatnya. Pelanggaran ini disebabkan kebutuhan ekonomi yang mendesak, dan kebutuhan biaya hidup sehari-hari dan biaya pendidikan sekolah/kuliah anak. Dalam Petunjuk Pelaksanaan Kegiatan Landreform Tahun 2015 secara tegas menyebutkan, bahwa bidang-bidang tersebut tidak boleh diperuntukan/dialihkan untuk tujuan lain selain daripada peruntukan dan penggunaan tanah yang ditetapkan dan dilarang memindahkan haknya baik sebagian atau keseluruhan, kecuali kepada pihak yang memenuhi persyaratan dengan izin tertulis dari pejabat berwenang sesuai ketentuan yang ditetapkan.

Petani yang telah menjual tanahnya pada umumnya juga menyisihkan uang hasil penjualan tanah redis untuk pembelian tanah pertanian di lokasi pedalaman yang relatif masih murah di desa tempat tinggal asalnya. Namun demikian ada juga petani penerima redis lain yang objek tanahnya tidak dijual, walaupun lokasinya terletak di tepi jalan aspal kabupaten berada di sekitar area Kampus PSDKU UNDIP. Ada juga beberapa gelintir petani yang menyewakan sebagian lahannya untuk café dan rumah makan (Handoko, 2020).

Permasalahan pengkaplingan perumahan/pemukiman ilegal bagi $425 \mathrm{KK}$ petani penerima redis, menurut penjelasan Handoko(2020), lokasi tanahnya terletak di area 65 (enam puluh) bidang tanah yang saling berbatasan. Hal ini telah direncanakan dan disepakati sejak kegiatan daftar nominatif peserta redis yang difasilitasi oleh FB.Omah Tani dan kesepakatan ini memang tidak diketahui oleh Tim Satuan Gugus Tugas Pelaksanaan Program Redistribusi Tanah Objek Landreform Kantor Pertanahan Kabupaten Batang.

Dalam pembelaannya, para petani berargumen: pertama, penyediaan lahan perumahan ilegal agar petani penerima redis "mendekatkan" diri pada lahannya, sehingga dapat memenuhi kewajiban memelihara kesuburan tanahnya sebagaimana dipersyaratkan dalam SK Pemberian HM nya. Kedua, pertimbangan pemilihan lahan yaitu berdasarkan KK yang awalnya masih satu keluarga, misal KK orang tua dan KK anaknya yang sudah berkeluarga; maka bidang tanah redis salah satu KK nya (milik anaknya) diserahkan untuk area lokasi pemukiman petani penerima redis. Ada yang membangun perumahan ilegal, terutama mereka yang telah mempunyai biaya dari menjual tanahnya, mereka ada juga yang melakukan sewa sebagian lahan yang diterima oleh petani penerima redis.

Dalam rangka pelaksanaan akses reform, telah dilaksanakan kesepakatan bersama antara Pemkab Batang, Kantah Kab. Batang PT. Bank Pembangunan Jawa Tengah, PT. Rimba Partikel Indonesia dan FB. Omah Tani untuk Pengembangan Tanaman Industri pada Lokasi reforma agraria di Desa Tumbrep pada tanggal 11 Februari 2016 (Budhiawan, Widarbo, 2020). Namun menurut Handoko (2020), manajemen akses reform tidak berjalan karena petani penerima redis takut tidak mampu mengembalikan dana pinjaman dari perbankkan. Sebagai solusi pemberdayaannya difasilitasi oleh FB. Omah Tani yakni dengan membagi tugas bagi anggota keluarga yang dewasa dalam satu KK petani penggarap untuk bekerja pada pabrik pengelolaan minyak asturi di Desa Trumbep (Handoko, 2021). Solusi lain yang 
sedang dirintis oleh FB.Omah Tani yakni bekerja sama dengan Badan Usaha Milik Desa (BUMDES) dengan membangun kios pasar, guna memasarkan produk panen pisang dari petani penerima redis (Handoko, 2020).

\section{Dampak Redistribusi Tanah UNDIP}

\section{Kebijakan Strategis Pembangunan PSDKU UNDIP}

Kebijakan program kerjasama UNDIP dengan Pemerintah Kabupaten Batang dengan mendirikan PSDKU adalah program strategis yang saling memberikan manfaat bagi kedua belah pihak. Bagi UNDIP, hal ini merupakan bagian dari pengembangan program PSDKU di Jawa Tengah seperti Pekalongan, Demak, Rembang, dan Batang merupakan yang pertama dan menjadi role model program PSDKU UNDIP. Contoh kampus utama UNDIP di Semarang yang semula di wilayah pusat kota, sebagian dipindah ke Kelurahan Tembalang, Kecamatan Tembalang. Upaya itu dilakukan untuk merubah daerah tersebut menjadi kawasan pendidikan dan perkembangan simpul ekonomi baru di sekitar kampus.

Perencanaannya digabungkan dengan kebijakan makro Pemkab Batang sebagai kampus hijau ramah lingkungan, mendukung Heaven of Asia dan Tahun Kunjungan Wisata 2022. Bagi Pemkab Batang pembangunan vokasi PSDKU UNDIP mempunyai nilai strategis sekaligus kebanggaan masyarakat Batang mempunyai perguruan tinggi negeri. hal itu berdampak positif bagi pengembangan kemajuan daerah tersebut dan mempunyai multiplier effect di bidang pendidikan dan juga melahirkan simpul ekonomi baru. Juga untuk mendukung kemajuan produksi bidang pertanian dan peternakan, membuka peluang usaha di banyak sektor bagi masyarakat, seperti jasa sewa kamar, kontrakan, rumah/ warung makan, laundry, pertokoan kebutuhan sehari-hari mahasiswa, dan jasa transportasi. Bahkan berkembang café, sarana olah raga di kampus maupun di luar kampus, sehingga mahasiswa sudah merasa nyaman beraktivitas di kawasan tersebut. Potensi wisata baru di kawasan alam pedesaan yang juga merupakan jalur menuju tempat wisata Dieng dan mendongkrak indeks pembangunan manusia (IPM).

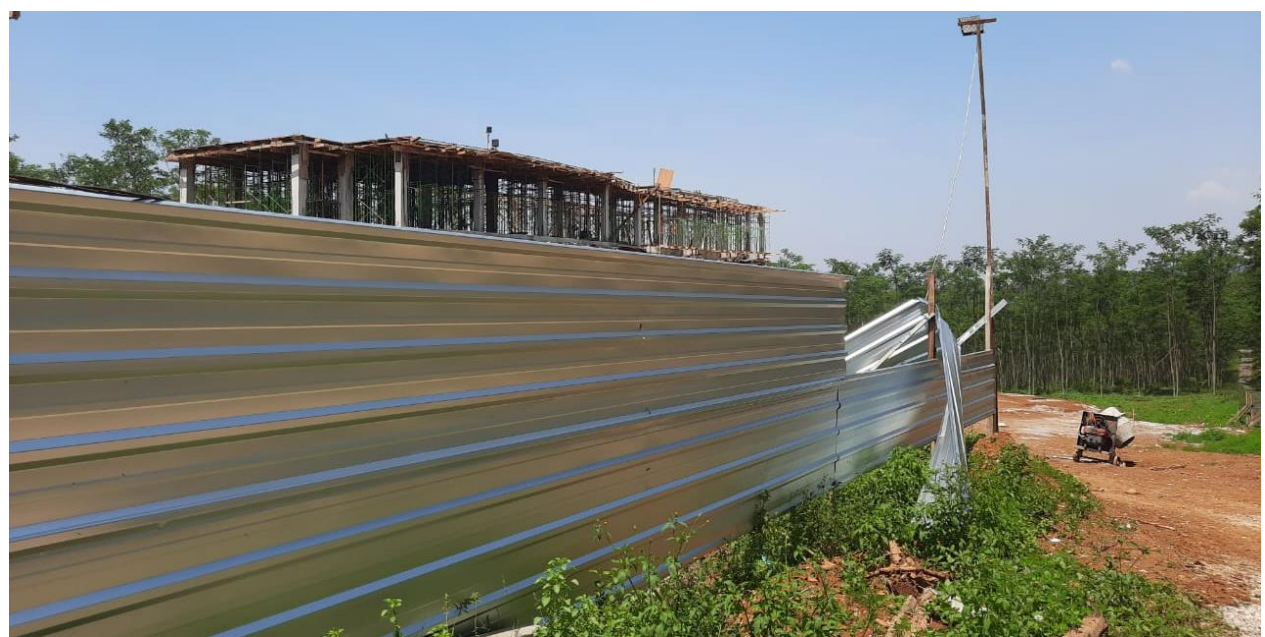

Gambar 2: Kampus PSDKU UNDIP Desa Trumbep Kec.Bandar Kab.Batang. Sumber gambar: Dokumentasi lapang, 2020 
Menurut Retno Dwi Irianto selaku Asisten Pemerintahan Desa dan Kesra Setda Pemkab Batang bahwa lokasi Desa Trumbep diarahkan untuk penelitian dan pengembangan di sektor peternakan sesuai dengan Revisi RTRW 2011-2030 yaitu sebagai kawasan pertanian dan peternakan. Lokasi ini sangat strategis dijadikan perguruan tinggi yang mempunyai andil utama di bidang pertanian dan peternakan. Perencanaan kawasan kampus digabungkan kegiatan dengan perencanaan kebijakan makro Pemkab Batang untuk mendukung Heaven of Asia dan Tahun Kunjungan Wisata 2022, sebagai kampus hijau ramah lingkungan (Suryoto,2020).

Hasil kunjungan bersama Tim Perencana Pembangunan UNDIP bahwa perencanaan pembangunan kampus akan menyesuaikan dengan situasi dan kondisi lingkungan sekitarnya, yakni di daerah pertanian, serta mengembangkan pusat pendidikan, dan penelitian, pembelajaran berorientasi pada produksi dan bisnis, kampus wisata edukasi, research and technology park, pengembangan domba dan minyak astiri. Untuk itu dibutuhkan pemberdayaan sumber daya manusia yang memiliki daya saing, cekatan dan tidak bergantung pada pihak lain bagi sekitar kampus (Suryoto,2020). Penjelasan Rektor UNDIP, proses administrasi PSDKU UNDIP relatif cepat karena mendapat dukungan sepenuhnya dari Pemerintah Kabupaten Batang sejak Tahun 2018. Peletakan batu pertama pembangunan pada tanggal 19-08-2020, ditargetkan selesai pada akhir tahun 2020. Pada tahap pertama dianggarkan Rp.10 miliar untuk membangun gedung 3 lantai; Pembangunan ini diharapkan menjadi contoh/model bagi PSDKU di sejumlah daerah Jawa Tengah, seperti Demak, Jepara, Rembang, dan Pekalongan. Sesuai dengan RTRW di Desa Trumbep akan dibuka Fakultas Pertanian dan Peternakan (Setyadi, 2020). Bupati Batang Wihaji menegaskan bahwa warga sudah lama bermaksud mempunyai perguruan tinggi apalagi negeri, sehingga pembangunan UNDIP dapat memberi dampak multiplier effect baik di bidang pendidikan dan juga melahirkan simpul ekonomi baru (Suryoto, 2020). Hal itu dapat juga mempengaruhi kemajuan masyarakat, terutama sektor ekonomi, mendukung potensi wisata, perubahan gaya hidup dan mendongkrak indeks pembangunan manusia (IPM) (Kutnadi,2020).

\section{Dampak bagi Lokasi Redistribusi}

Dampak pembangunan kampus PSDKU UNDIP bagi lokasi Reforma agraria melalui program redistribusi bekas HGU No.1/Tratak Perkebunan tidak berbanding lurus dengan dampak positif bagi kawasan di luar lokasi redis. Kondisi tersebut menyebabkan pengalihan secara ilegal terhadap 40 (empat puluh) bidang tanah redis kepada investor dan pengaplingan area lokasi perumahan $425 \mathrm{KK}$ petani penerima redis atas 65 bidang tanah.

Petani penerima redis telah memahami bahwa bidang tanah redis dilarang diperuntukkan, digunakan atau dialihkan untuk tujuan selain pertanian sebagian atau seluruhnya dalam waktu 10 tahun, sebagaimana tercantum dalam SK Pemberian HM dan sertipikat yang diterima. Faktanya terjadi pengalihan secara 
ilegal melalui jual beli di bawah tangan kepada pihak investor sejak Tahun 2019. Kegiatan pembangunan kampus memang baru dilaksanakan sejak peletakan batu pertama Tanggal 19 Agustus 2020, tetapi proses administrasinya mulai dari perjanjian kerja sama, proses hibah aset Pemkab Batang kepada UNDIP melalui proses persetujuan DPRD Batang memang harus sesuai peraturan perundangan dan membutuhkan waktu. Hal ini merupakan waktu yang relatif singkat, kurang dari satu setengah tahun.

Kegiatan persiapan pembangunan kampus PSDKU UNDIP di kawasan berdekatan dengan lokasi reforma agraria sejak tahun 2018 ini tentunya dengan cepat diketahui oleh warga masyarakat, bukan hanya di kawasan Desa Trumbep, tetapi juga investor melalui internet. Dampak kehadiran PSDKU UNDIP tentunya berakibat pada kenaikan harga tanah terutama yang posisinya di tepi Jalan Raya Bandar (Kabupaten). Kenaikannya terjadi secara signifikan, kurang lebih mencapai 3 (tiga) kali lipat, dari semula Rp.100.000-200.000 menjadi Rp.500.000 rupiah permeter. Sedangkan yang berbatasan sebelah baratnya mengalami kenaikan 4 (empat) kali lipat, dari Rp.50.000 menjadi Rp.200.000. Adapun alasan dijualnya tanah redis tersebut oleh para petani penerima redistribusi adalah untuk membiayai kebutuhan sehari-hari dan pendidikan anak. Tentu saja masyarakat menganggap tanah tersebut tidak sesubur tanah yang berada di tepi sungai yang berada di dalam blok lokasi redis, untuk dimanfaatkan sebagai lahan sawah.

Adapun daftar 40 (empat puluh) nama petani penerima redis yang mengalihkan HM ini diketahui oleh Ketua Omah Tani dan Kepala Desa Tumbrep, berdasarkan keterangan Tahroni (2020) berikut daftar nama petani subjek redistribusi Desa Tumbrep yang menjual tanahnya tidak sesuai dengan aturan:

Tabel 1. Daftar Nama 40 Petani Redistribusi Desa Tumbrep Yang Menjual Tanahnya Sampai Dengan Tahun 2020

\begin{tabular}{llllll}
\hline No. & Nama & Luas $\left(\mathbf{m}^{2}\right)$ & No. & Nama & Luas $\left(\mathbf{m}^{2}\right)$ \\
\hline 1 & Dasi & 1.519 & 21 & Caroni & 1.813 \\
2 & Yaeni & 1.622 & 22 & Duriyah & 1.624 \\
3 & Wahyuni & 1.450 & 23 & Wasdirun & 1.952 \\
4 & Ambari & 1.450 & 24 & Khomsatun & 1.820 \\
5 & Supardi & 1.480 & 25 & Rahmadi & 1.439 \\
6 & Muinah & 1.439 & 26 & Purwati & 1.850 \\
7 & Suprayetno & 1.583 & 27 & Raib & 1.656 \\
8 & Suratman & 1.703 & 28 & Nasehatin & 1.590 \\
9 & Mujarob & 1.626 & 29 & Hairudin & 1.564 \\
10 & Casri & 1.573 & 30 & Dianto & 1.598 \\
11 & Wahadi & 1.400 & 31 & Kusrin & 1.577 \\
12 & Kasmoen & 1.521 & 32 & Tahril & 1.681 \\
13 & Sumanto & 1.528 & 33 & Suparti & 1.565 \\
14 & Suwahno & 1.573 & 34 & Ngatmi & 1.577 \\
15 & Karmidi & 1.332 & 35 & Samsuri & 1.685 \\
\hline
\end{tabular}




\begin{tabular}{llllll}
\hline No. & Nama & Luas $\left(\mathbf{m}^{2}\right)$ & No. & Nama & Luas $\left(\mathbf{m}^{2}\right)$ \\
\hline 16 & Tasmoen & 1.430 & 36 & Wiyoto & 1.828 \\
17 & Warso & 1.353 & 37 & Tahroji & 1.895 \\
18 & Sunariyah & 1.361 & 38 & Basuki & 1.934 \\
19 & Ery Rusmiati & 1.485 & 39 & Nurhadi & 1.634 \\
20 & Darsono & 1.950 & 40 & Samiah & 1.635 \\
\hline
\end{tabular}

Sumber: Tahroni,2020

Apabila dialihkan kepada pihak lain yang memenuhi persyaratan, hal ini tentunya terhadap pembeli atau calon penerima tanah redis tidak berakibat sebagai subjek tanah absentee dan berdasarkan Pasal 10 UU No. 5 Tahun 1960 (UUPA) berkewajiban memelihara dan meningkatkan kesuburan tanah pertanian redis, dilarang peruntukkan, penggunaan selain tanah pertanian. Sedangkan mengenai izin tertulis dari pejabat yang berwenang sesuai ketentuan yang ditetapkan. Hal ini perlu diatur siapa yang berwenang. Ex-officio Kepala Kantor Pertanahan Kabupaten Batang selaku pejabat yang menerbitkan SK pemberian HM redis sebagai alas hak yang mendasar dan penerbitan sertipikatnya; apa sudah berwenang memberikan izin tertulis, atau masih perlu dikonsultasikan Kepada Kepala Kantor Wilayah BPN Provinsi Jawa Tengah mengingat redistribusi tanah adalah bagian dari reforma agraria merupakan Program Strategis Nasional (PSN).

Masalah pengkaplingan perumahan ilegal bagi $425 \mathrm{KK}$ petani penerima redistribusi tanah ini sudah direncanakan di awal saat pengusulan daftar nominatif yang difasilitasi oleh FB. Omah Tani. Pengkaplingan tanah ini dilakukan dengan dalih filosofi keadilan dan kemanfaatan, namun pada prakteknya melanggar nilai kepastian hukum. Terhadap beberapa KK yang awalnya berasal dari KK orang tuanya, disepakati ditempatkan dikelompokkan menjadi 1 area blok 65 bidang HM redis untuk diserahkan guna penyediaan akses pengkaplingan perumahan seluruh petani penerima redis, sedangkan mereka menggarap bersama atas bidang keluarganya yang lain, atau perjanjian sewa dengan pemilik tanah redis yang lain. Berdasarkan hal tersebut masalah ini memang tidak terkait langsung dari dampak pembangunan Kampus PSDKU UNDIP di Desa Trumbep. Namun demikian pelaksanaan pembangunan perumahan ilegal tersebut mulai aktif bergerak setelah sebagian dari 40 pemilik bidang tanah redistribusi telah dijual kepada pihak investor sebagai dampak pembangunan kampus PSDKU UNDIP tersebut. Mereka berasumsi dengan diperbolehkan pembangunan UNDIP yang merupakan juga berasal dari bekas HGU No.1/Tratak di area peruntukkan penggunaan pertanian dengan penyesuaian revisi RTRW nya, membuka peluang bagi mereka juga memperoleh kebijakan pembangunan perumahan sebagai perkampungan reforma agraria.

Merujuk pada Pasal 25 Perpres No. 86 Tahun 2018, petani penerima redistribusi tanah atau subjek dari reforma agraria dilarang menelantarkan tanah yang dirediskan atau Tanah Objek Reforma Agraria (TORA). Apabila subjek reforma agraria memindahtangankan atau mengalihkan hak atas TORA atau mengganti 
atau mengalih fungsikannya, maka wajib memenuhi persyaratan yakni izin dari Menteri ATR/Kepala BPN melalui kepala kantor pertanahan letak objek redistribusi tanah berada. Berdasarkan hal-hal tersebut di atas, sebagai solusi yang komprehensif untuk permasalahan reforma agraria pasca redistribusi tanah, Kepala Kantor Pertanahan Kabupaten Batang selaku Ketua Harian GTRA dapat memasukkan ke dalam GTRA Kabupaten guna putusan penyelesaiannya sebagai rekomendasi pengajuan izin kepada Menteri ATR/Kepala BPN. Apabila diperlukan peran serta tokoh FB. Omah Tani sebagai tokoh masyarakat dapat dimasukkan menjadi Anggota GTRA.

Berkaitan dengan usulan konsep pemberdayaan petani terhadap perubahan situasi kondisi lingkungan dampak dari adanya Kampus UNDIP dengan kewajiban memelihara kesuburan peruntukkan penggunaan tanah pertaniannya, maka membutuhkan pemikiran-pemikiran yang strategis sebagai solusinya. Pertama, mengusulkan perlu adanya koordinasi yang harmonis antara petani penerima redistribusi tanah yang difasilitasi oleh FB. Omah Tani dan peran serta GTRA, guna mensinergikan komitmen UNDIP dengan program reforma agraria bagi petani penerima redistribusi tanah di sektor pertanian dan peternakan dengan tidak melanggar kewajiban memelihara kesuburan tanahnya. Kedua, mengembangkan dan meningkatkan sumber daya manusia bagi petani penerima redistribusi tanah agar profesional sebagai petani dan belajar menjadi peternak. Ketiga, mengikutsertakan petani penerima redistribusi tanah, melakukan pembelajaran dan pelatihan yang berorientasi pada produksi dan bisnis pertanian dan peternakan dengan penggunaan teknologi aplikatif. Sementara pemasaran hasil panen produk petani penerima redistribusi tanah termasuk pisang, pengembangan domba, dan minyak astiri, serta mengeksplor objek wisata yang dapat digali di lokasi objek redistribusi termasuk di tepi Sungai Tambangan.

\section{E. Kesimpulan}

Berdasarkan analisis dan uraian tersebut di atas dapat disimpulkan, pembangunan Kampus PSDKU UNDIP memberikan dampak positif bagi masyarakat sekitar termasuk penerima radis. Pertama, berupa perkembangan kemajuan simpul ekonomi yang memberi multiplier effect di kawasan Desa Trumbep dan sekitarnya terutama di bidang pertanian dan peternakan, khususnya bagi lokasi reforma agraria yang letaknya berdampingan dan keduanya sama-sama berasal dari Bekas HGU No.1/Trumbep. Kedua, diharapkan berguna dan bermanfaat bagi peningkatan kualitas keterampilan petani penerima redis melalui Program Vokasi UNDIP berupa pendidikan, pembelajaran, pelatihan, teknologi siap pakai dan pemasaran produknya serta peningkatan kualitas kesuburan tanah bagi lokasi reforma agraria. Ketiga, menggali sumber-sumber lain, antara lain peluang-peluang kemandirian wirausaha dan atau bekerjasama dengan pihak ketiga, termasuk Badan Usaha Milik Desa yang dapat difasilitasi FB. Omah Tani yang selama ini berjasa memfasilitasi petani penerima redistribusi tanah. 
Mengatasi dampak negatif dari pembangunan Kampus PSDKU UNDIP, baik pelanggaran pengalihan TORA berupa penjualan tanah redistribusi secara ilegal terhadap 40 bidang hasil redistribusi tanah kepada pihak ketiga (investor), dan pengalihfungsian TORA berupa pengkaplingan pemukiman petani penerima redis. Solusinya yaitu wajib memenuhi persyaratan izin Menteri ATR/Kepala BPN melalui Kepala Kantor Pertanahan Kabupaten Batang disertai hasil rekomendasi GTRA Kabupaten Batang.

\section{Daftar Pustaka}

Budiawan, H. \& Widarbo, K. (2020). Pengalihan Ilegal Tanah Redistribusi Bekas HGU No.1 PT. Tratak di Desa Tumbrep Kecamatan Bandar Kabupaten Batang. Laporan Hasil Penelitian STPN. Yogyakarta.

Dempo, A.A.P., Salim, M.N., \& Farid, A. H. (2021). Evaluasi Pelaksanaan Redistribusi Tanah Eks Kawasan Hutan di Kabupaten Musi Rawas. Jurnal Tunas Agraria, 4(1), 1-21.

Handoko, Tokoh/pengacara (FB.Omah Tani, Desa Tumbrep,Kec.Bandar, Batang, 15-16 Okt.2020,wawancara.

Hatta Kepala Kantor Kantor Pertanahan Kabupaten Batang, 12 Okt. 2020, wawancara.

Hidayat, M.F., Luthfi, A.N., \& Salim, M.N. (2020). Desain Reforma Agraria Inklusif untuk Program Keluarga Harapan dan Kaum Difabel di Kabupaten Kediri. Jurnal Tunas Agraria, 3(1), 1-29.

Istiningdyah, R., Sutaryono, \& Wahyuni, W. (2018). Kontribusi Redistribusi Tanah Terhadap Kenaikan Pendapatan Masyarakat di Jawa Tengah. Jurnal Tunas Agraria, 1(1), 20-46.

Ishaq, Metode Penelitian Hukum dan Penulisan Skripsi, Tesis serta Disertasi, 2017, Alfabeta, Bandung.

Kantor Staf Kepresidenan, Strategi Nasional Pelaksanaan Reforma Agraria 2016-2019, Arahan dari Kantor Staf Presiden, Jakarta, 28 April 2016.

Kutnadi (16 Juni 2020) Pembangunan Gedung Undip Batang dianggarkan Rp.10miliar https://jateng.antaranews.com/berita/317308/pemkabanggarkan-pembangunan-psdku-undip-rp10-miliar

Mujiati \& Aisiyah, N. (2014). Perkembangan Peraturan Mengenai Redistribusi Tanah Dalam Rangka Reforma Agraria Di Kabupaten Boyolali. BHUMI: Jurnal Agraria dan Pertanahan, 1(39), 457-469.

Mujiburrohman, D.A. (2018). Menyoal Penafsiran Tanah Telantar. Jurnal Yudisial, 11(1), 1-22.

Mujiburohman, D.A. (2019). Penegakan Hukum Penertiban dan Pendayagunaan Tanah Terlantar. Yogyakarta: STPN Press.

Riyadi, A.D., Salim, M.N., \& Mujiati. (2020). Pemberdayaan Masyarakat Pasca Kegiatan Ajudikasi di Desa Sumogawe Kecamatan Getasan Kabupaten Semarang. Jurnal Tunas Agraria, 3(2), 20-39. 
Saputra, L.A. (2015). Peran Omah Tani Dalam Memperjuangkan Hak Atas Tanah Petani di Desa Tumbrep Kecamatan Bandar Kabupaten Batang. Skripsi pada Jurusan Politik Dan Kewarganegaraan Fakultas IImu Sosial Universitas Negeri Semarang 2015.

Setyadi, Wahyu (20 Agustus 2020) Peletakan Batu Pertama Kampus PSDKU Undip di Kab. Batang.https://psdku.undip.ac.id/peletakan-batupertama-kampus-psdku-undip-di-kab-Batang

Sumiati, S. Kasi Penataan Pertanahan dan Pemberdayaan (PPP), (Kantor Pertanahan Kabupaten Batang, Kasi P3, 13 Oktober 2020,wawancara.

Suryoto, Arif. (2020, Juni) Undip Bangun Kampus di Batang, Rampung Desember 2020 diakses pada tanggal 17 Juni 2020 dari https://www.suaramerdeka.com/regional/pantura/231746-undipbangun-kampus-di-batang-rampung-desember-2020?page=1

Sutadi, R.D., Luthfi, A.N., \& Mujiburrohman, D.A. (2018). Kebijakan Reforma Agraria di Indonesia (Kajian Komparatif Tiga Periode Pelaksanaan: Orde Lama Orde Baru, dan Orde Reformasi). Jurnal Tunas Agraria, 1(1 Sept), 192-218.

Tahroni, Ketua FB.Omah Tani, Batang.15 Oktober 2020, wawancara.

Utami, W. (2017) Capacity Building dalam ReTaforma Agraria (Model Capacity Building di Batang, Jateng) Prosiding pada Seminar Nasional: Problematika Pertanahan dan Strategi Penyelesaiannya.STPN bekerjasama dengan Fakultas Hukum Universitas Trisakti. Oktober 2017.

\section{Peraturan Perundang-Undangan}

Ketetapan MPR No.IX/MPR/2001 Tentang Pembaruan Agraria dan Pengelolaan Sumber Daya Alam.

UU No.5 Th.1960 Tentang Peraturan Dasar Pokok-Pokok Agraria (UUPA).

Perpres No.86 Th.2018 Tentang Reforma Agraria.

Peraturan Bupati Batang No 07 Tahun 2011 Tentang RTRW Kabupaten Batang Tahun $2011-2031$. 